\title{
PENGARUH PEMANFAATAN AMPAS KEDELAI DAN ONGGOK TERFERMENTASI RHIZOPUS SP DALAM KONSENTRAT DOMBA MERINO TERHADAP PERTAMBAHAN BOBOT BADAN DAN KONSUMSI PAKAN
}

\author{
Dwi Fiky Evavianto; Dimas Pratidina Puri Astuti Hadiyani; Walulyo Edi Susanto \\ Fakultas Peternakan Universitas Kanjuruhan Malang \\ J1. S. Supriadi No.48 Malang \\ Email: puriastuti@unikama.ac.id
}

\begin{abstract}
This study aims to determine the benefits of soybean husk and onggok fermented rhizopus sp in feed merino sheep concentrate of body weight gain and feed intake. Materials used in the study is as much as 12 merino sheep and the methods used by the randomized trial (RAK) using the PO as controls (100\% concentrate); P1 (AOT concentrate 90\% + 10\%); P2 (AOT concentrate $80 \%+20 \%$ ); P3 (AOT Concentrate $70 \%+30 \%$ ). The results of the study with $30 \%$ of AOT gift giving weight increase of $25.3 \mathrm{~g} /$ tail significantly different $(\mathrm{P}<0.05)$ and feed consumption P0 : 215, 27g / tail, P1 : 203, 13g / eco, P2: 219,24g / tail, P3: 190.72 not significantly different $(\mathrm{P}>0.05)$, it can be concluded that the AOT replace concentrate when substituted have the same content to concentrate on P0, P1, P2, and P3. From the results of this study cuncluded that the addition soybean husk and onggok fermented rhizopus sp in feed merino sheep concentrate can increase body weight gain and low consumption level but have a good nutrition with the level of gift $30 \%$.
\end{abstract}

Keywords : Merino Sheep, Soybean Husk, Onggok, Body Weight Gain And Feed Intake

\begin{abstract}
ABSTRAK
Penelitian ini bertujuan untuk mengetahui manfaat dari kulit kedelai dan onggok fermentasi Rhizopus sp dalam pakan merino domba konsentrat dari bobot badan dan konsumsi pakan. Bahan yang digunakan dalam penelitian ini adalah sebanyak 12 domba dan metode yang digunakan oleh uji coba secara acak (RAK) dengan menggunakan PO sebagai kontrol (100\% konsentrat); P1 (AOT berkonsentrasi 90\% + 10\%); P2 (AOT berkonsentrasi $80 \%+20 \%$ ); P3 (AOT Konsentrat $70 \%+30 \%$ ). Hasil penelitian dengan $30 \%$ dari hadiah AOT memberikan peningkatan berat $25,3 \mathrm{~g} /$ ekor yang berbeda secara signifikan $(\mathrm{P}<0,05)$ dan pakan $\mathrm{P} 0$ konsumsi:. 215, 27g / ekor, P1: 203, 13 g / eco, P2: 219,24g / ekor, P3: 190,72 tidak berbeda nyata $(\mathrm{P}<0,01)$, dapat disimpulkan bahwa AOT menggantikan konsentrat ketika diganti memiliki konten yang sama untuk berkonsentrasi pada P0, P1, P2, dan P3. Dari hasil penelitian ini diaimpilkan bahwa penambahan kulit kedelai dan onggok fermentasi Rhizopus sp dalam pakan konsentrat domba merino dapat meningkatkan bobot badan dan tingkat konsumsi yang rendah tetapi memiliki gizi yang baik dengan tingkat pemberian $30 \%$.
\end{abstract}

Kata kunci: Merino Sheep, Kedelai Husk, Onggok, Tubuh Berat Badan Dan Konsumsi Pakan

\section{PENDAHULUAN}

Domba merupakan salah satu ternak ruminansia yang dimana ternak ruminansia adalah ternak yang memiliki lambung empat yang terdiri dari rumen, retikulum, omasum, dan abomasum dan juga mengalami proses memamahbiak atau proses pengembalian makanan dari lambung ke mulut untuk di kunyah.

Sample ternak yang digunakan dalam penelitian adalah jenis domba merino, domba merino ini baik untuk diternakan ditempat yang bersuhu dingin seperti daerah pegunungan. Keunggulan domba merino ini terletak pada kuantitas dagingnya yang 
tinggi. Parameter yang diamati dalam penelitian ini adalah pertumbuhan berat badan dan tingkat konsumsi pakan (ampas kedelai dan onggok terfermentasi rhizopus sp dalam konsentrat domba merino).

Domba merupakan ternak yang memiliki sifat toleransi tinggi terhadap bermacam-macam pakan hijauan serta mempunyai daya adaptasi yang baik terhadap berbagai keadaan lingkungan. Pengembangan domba mempunyai prospek yang baik karena disamping untuk memenuhi kebutuhan daging di dalam negeri, juga memiliki peluang sebagai komoditas ekspor. Untuk mendukung pengembangan domba nasional di masa yang akan datang, jumlah dan mutu bibit merupakan faktor produksi yang sangat strategis dan menentukan keberhasilan program pembangunan peternakan.

Pakan utama ternak ruminansia adalah hijauan yaitu sekitar 60-70\%, namun demikian karena ketersediaan pakan hijauan sangat terbatas maka pengembangan peternakan dapat diintegrasikan dengan usaha pertanian sebagai strategi dalam penyediaan pakan ternak melalui optimalisai pemanfaatan limbah pertanian dan limbah agroindustri pertanian ( Mersyiah, 2005). Banyak upaya yang dapat dilakukan untuk memaksimalkan ketersediaan pakan ternak. Salah satu upaya yang dapat dilakukan adalah dengan menggunakan produk fermentasi.

Pencarian bahan pakan alternatif harus diupayakan agar tidak tergantung pada bahan pakan hijauan, misalnya dengan memanfaatkan limbah agroindustri seperti ampas kedelai dan onggok yang sangat berlimpah dan harganya murah. Teknologi fermentasi harus diterapkan untuk mengatasi kelemahan limbah tersebut yang bernilai nutrisi rendah. Selain dapat meningkatkan nilai nutrisi limbah, dengan fermentasi dapat juga mengubah bahan pakan yang sulit dicerna menjadi mudah dicerna, mengahasilkan aroma dan flavour yang khas, serta dapat menghilangkan racun dari bahan limbah. Dalam melakukan proses fermentasi aktifitas mikroorganisme dipengaruhi oleh $\mathrm{pH}$, suhu, komposisi zat makanan dan adanya zat inhibitor ( Komar,A. 2004).

Konsentrat adalah suatu bahan pakan yang digunakan bersama bahan pakan lain untuk meningkatkan keseimbangan nutrisi dari keseluruhan bahan pakan dan dicampur sebagai suplemen (pelengkap) atau pakan pelengkap. Bahan pakan digolongkan menjadi 3 yaitu pakan hijauan, pakan penguat dan pakan tambahan. 1) Pakan hijauan yaitu semua bahan pakan yang berasal dari tanaman ataupun tumbuhan berupa daun-daunan. Yang termasuk hijauan adalah rumput, leguminosa dan tumbuhan lain. Semuanya dapat diberikan untuk ternak dengan 2 macam bentuk yaitu berupa hijauan segar dan kering. 2) Pakan penguat yaitu pakan yang berkonsentrasi tinggi dengan kadar serat kasar relative rendah dan mudah dicerna. Bahan pakan penguat meliputi bahan pakan yang berasal dari 


\section{Jurnal Sains Peternakan}

Vol 6 No 2, Desember 2018, 34-41

ISSN 2579-4450

biji-bijian seperti jagung giling, menir, hasil ikutan pertanian atau pabrik seperti dedak, bungkil kelapa, bungkil kedelai, tetes yang berfungsi untuk meningkatkan dan memperkaya nilai nutrient pada bahan pakan lain yang nilai nutriennya rendah. 3) Pakan tambahan biasanya berupa vitamin, mineral, dan urea.

Bahan pakan merupakan biaya produksi terbesar dalam usaha peternakan domba sehingga untuk menekan biaya produksi dilakukan dengan cara menekan biaya pakan melalui penggunaan pakan bahan pakan alternatif yang murah, ekonomis dalam penggunaannya, tersedia terus menerus serta mengandung nutrien yang berkualitas yang diperlukan ternak. Pengunaan bahan alternatif tersebut dapat dilakukan salah satunya dengan memanfaatkan limbah industri pengolahan hasil pertanian seperti ampas tempe.

Ampas tempe merupakan salah satu limbah industri pembuatan tempe berupa kulit kedelai (kupasan kulit ari) yang dapat dijadikan sumber serat kasar. Ampas tempe mempunyai sifat cepat busuk dan baunya dapat mencemari lingkungan sehingga apabila diberikan pada ternak perlu dikeringkan terlebih dahulu. Ampas tempe kering mempunyai kandungan $14,53 \%$ protein kasar, 52,91\% TDN, 54,16 serat kasar dan masing-masing atas dasar BK (Setyorini 2007).

Onggok atau atau ampas sisa dari tapioka merupakan hasil sampingan dari pembuatan tapioka. Onggok ini dapat digunakan sebagai salah satu konsentrat pakan ternak sapi, kambing, atau ungas. Karena kandungan protein yang rendah kurang dari 5\% limbah tersebut jarang dimanfaatkan oleh para peternak, namun dengan teknik fermentasi kandungan protein di dalam onggok tersebut dapat ditingkatkan, sehingga onggok terfermentasi dapat digunakan sebagai pakan alternatif untuk ternak

\section{MATERI DAN METODE}

Materi yang digunakan dalam penelitian ini berupa domba merino sejumlah 12 ekor yang berumur 1,5 tahun. Bahan pakan domba merino yang terdiri dari: (1) hijauan berupa jerami jagung, (2) pakan konsentrat, (3) inokulum rhizopus sp, (4) ampas kedelai, (5) onggok.

\section{Tahapan Penelitian}

Tahap Pendahuluan

a. Ampas kedelai di peras dan di jemur hingga kering.

b. Onggok di jemur hingga kering.

c. Setelah semua nya kering, kemudian ampas kedelai dan onggok dengan perbandingan 1:3 di campur dengan Rhizophus Sp sebanyak $0.6 \%$ hingga merata dan difermentasi \pm selama 3 hari kemudian di angin-anginkan. 


\section{Jurnal Sains Peternakan}

Vol 6 No 2, Desember 2018, 34-41

ISSN 2579-4450

d. Kemudian di masukkan ke dalam karung yang bersih.

Metode yang digunakan dalam penelitian ini adalah metode percobaan lapang dengan menggunakan rancangan acak kelompok (rak). Jumlah perlakuan sebanyak 4 dan masing-masing perlakuan terdiri dari 3 kali ulangan. Perlakuan yang diberikan adalah tingkat penambahan ampas kedelai dan onggok terfermentasi rhizopus $s p$ dalam pakan konsentrat. pakan kontrol diberikan tanpa penambahan ampas kedelai dan onggok terfermentasi rhizopus sp. Penambahan ampas kedelai dan onggok terfermentasi rhizopus $s p$ (aot) diberikan secara bertingkat. Adapun pakan perlakuan disusun dengan tingkat (\%) ampas kedelai dan onggok terfermentasi rhizopus sp sebagai berikut:

P0 : Hijauan $50 \%+$ pakan konsentrat (tanpa penambahan aot)

P1 : Hijauan $50 \%+$ pakan konsentrat $40 \%+$ aot $10 \%$

P2 : Hijauan $50 \%+$ pakan konsentrat $30 \%+$ aot $20 \%$

P3 : Hijauan $50 \%+$ pakan konsentrat $20 \%+$ aot $30 \%$

Keterangan: aot (ampas kedelai dan onggok terfermentasi)

Parameter yang diamati dalam penelitian ini adalah :

1. Dalam perwujudannya, proses pertumbuhan ternak akan terjadi pertambahan bobot badan dan untuk menjaga keseimbangan biologis maka setiap pertumbuhan komponen-komponen tubuh akan diikuti dengan semakin meningkatnya semua ukuran tubuh (Soeroso, 2004).

2. Palatabilitas merupakan

sifat performansi bahan-bahan pakan sebagai akibat dari keadaan fisik dan kimiawi yang dimiliki oleh bahan-bahan pakan yang dicerminkan oleh organoleptiknya seperti kenampakan, bau, rasa (hambar, asin, pahit), tekstur dan temperaturnya.

Data dianalisis dengan analisis ragam, apabila berbeda dilanjutkan dengan uji BNJ. 


\section{HASIL DAN PEMBAHASAN}

\section{Pertambahan Bobot Badan}

Tabel 1. Pertambahan Bobot Badan Domba Domba merino/Ekor (Kg)

\begin{tabular}{lcccrr}
\hline Perlakuan & Ulangan 1 & Ulangan 2 & Ulangan 3 & Total & Rata rata \pm sd \\
\hline P0 & 7,5 & 3,2 & 7,4 & 18,1 & 6,0 \\
P1 & 5,3 & 4,1 & 4,3 & 13,7 & 4,6 \\
P2 & 8,1 & 7,5 & 8,2 & 23,8 & 7,9 \\
P3 & 8,6 & 8,5 & 8,2 & 25,3 & 8,4 \\
\hline
\end{tabular}

Data rata-rata pertumbuhan berat badan per ekor per hari dari keempat perlakuan selama penelitian disajikan pada tabel di atas. Hasil analisis statistik menunjukan bahwa pengaruh ampas kedelai dan onggok terfermentasi rhizopus sp dalam konsentrat domba berpengaruh nyata terhadap pertambahan bobot badan domba, yaitu rataan P0 $(6,0)$ lebih besar dari rataan P1 $(4,6)$ dan rataan P3 $(8,4)$ lebih besar dari rataan P2 $(7,9)$. Data ini tersaji pada grafik 4.1.2 secara analisis ragam rancangan acak kelompok (RAK).

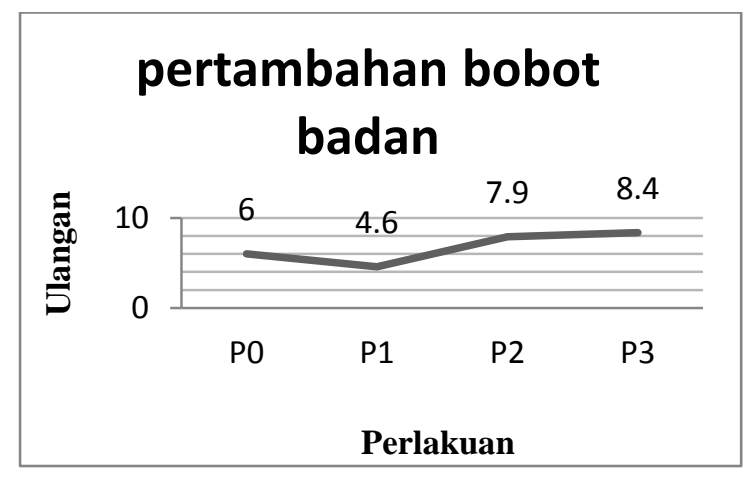

Grafik 1. Pertambahan Bobot Badan Domba.

Dari grafik 1 diketahui bahwa pemanfaatan ampas kedelai dan onggok terfermentasi rhizopus sp, memiliki dampak positif yaitu kecendurungan peningkatan berat badan domba merino jantan. Hasil analisis ragam menunjukan bahwa penggunaan ampas kedelai dan onggok terfermentasi rhizopus sp dalam pakan domba berbeda nyata, hal ini berarti penambahan pakan ampas kedelai dan onggok terfermentasi rhizopus sp sampai taraf $30 \%$ berpengaruh nyata terhadap pertambahan bobot badan.

Penggunaan ampas kedelai dan onggok terfermentasi rhizopus sp sampai taraf $30 \%$ dari total ransum mempengaruhi pertambahan bobot badan domba merino. PBB tertinggi terdapat pada P3 yang merupakan pemberian AOT sebanyak 30\% hal ini disebabkan oleh kemampuan ternak mencerna protein yang tersedia di AOT dan peningkatan kandungan nutrisi yang berada di Produk fermentasi, hal ini sesuai dengan 


\section{Jurnal Sains Peternakan}

Vol 6 No 2, Desember 2018, 34-41

ISSN 2579-4450

pernyataan ( Mirnawati,2007) Pakan yang mengalami fermentasi biasanya mempunyai nilai nutrisi yang lebih baik dari bahan asalnya. Fermentasi dapat meningkatkan kandungan nutrien dan nilai manfaat dari bahan asal. Bahan yang mengalami fermentasi biasanya mempunyai kandungan nutrien yang lebih tinggi dibandingkan dengan bahan asalnya.

\section{Konsumsi Pakan}

Tabel 2. Tingkat Konsumsi Pakan Domba Merino/ekor (Kg)

\begin{tabular}{|c|c|c|c|c|c|}
\hline Perlakuan & Ulangan 1 & Ulangan 2 & Ulangan 3 & Total & $\begin{array}{c}\text { Rata } \\
\text { rata } \pm \text { sd }\end{array}$ \\
\hline $\mathrm{P} 0$ & 68,04 & 82,49 & 64,74 & 215,27 & 71,76 \\
\hline $\mathrm{P} 1$ & 59,11 & 78,29 & 65,73 & 203,13 & 67,71 \\
\hline $\mathrm{P} 2$ & 68,70 & 65,74 & 84,80 & 219,24 & 73,08 \\
\hline $\mathrm{P} 3$ & 57,38 & 62,54 & 70,80 & 190,72 & 63,57 \\
\hline
\end{tabular}

Dari perhitungan rata-rata didapatkan nilai konsumsi pakan yang paling tinggi ada di P3 (hijauan 50\% + konsentrat 20\% + AOT 30\%) dengan total jumlah konsumsi pakan rataan P3 $(63,57 \mathrm{~g})$, tetapi secara analisis ragam menghasilkan nilai Fhitung < Ftabel 0,05 yang tidak berbeda nyata. Data ini tersaji pada grafik di bawah ini, secara analisis ragam rancangan acak kelompok (RAK)

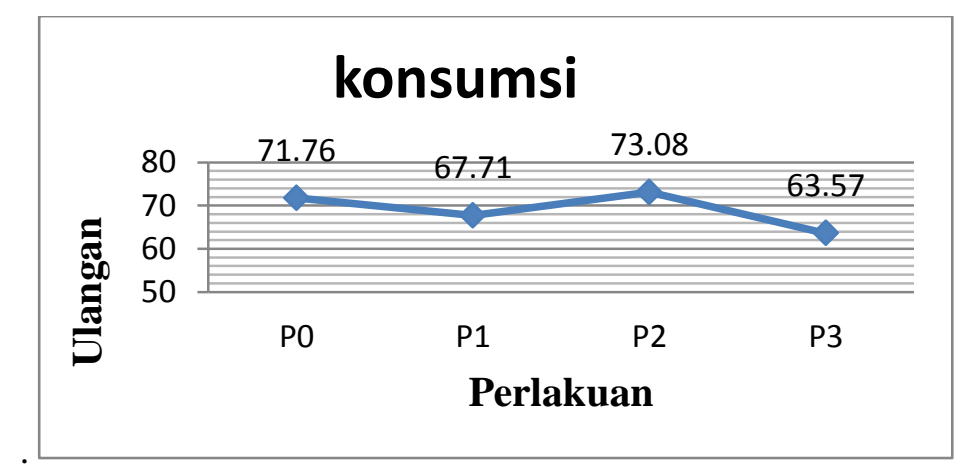

Grafik 2. Konsumsi Pakan Domba Merino

Berdasarkan grafik 2 diketahui bahwa pemanfaatan ampas kedelai dan onggok terfermentasi rhizopus sp pakan domba tidak berbeda nyata. Hal ini berarti penambahan pakan ampas kedelai dan onggok terfermentasi rhizopus sp sampai taraf $30 \%$ tidak berpengaruh terhadap tingkat konsumsi domba merino. Dari hasil perhitungan PBB pemberian AOT berbeda nyata sedangkan pada konsumsi tidak berbeda nyata hal ini disebabkan oleh tingkat kesukaan ternak terhadap bahan pakan menurun tetapi kandungan nutrein yang dicerna lebih tinggi. Hal ini sesuai dengan pernyataan (Ayuni, 2005) yang menyatakan bahwa tingkat konsumsi ransum banyak ditentukan oleh 


\section{Jurnal Sains Peternakan}

Vol 6 No 2, Desember 2018, 34-41

ISSN 2579-4450

palatabilitas (bau, warna, dan tekstur), sistem tempat dan pemberian pakan serta keadaan kandang.

\section{Kesimpulan}

Dari hasil penelitian dapat disimpulkan bahwa pemanfaatan ampas kedelai dan onggok terfermentasi Rhizopus sp dalam konsentrat domba merino dapat meningkatkan pertambahan bobot badan dan tingkat konsumsi pada ternak rendah tetapi memiliki nilai nutrisi yang baik dengan taraf pemberian AOT sebanyak $30 \%$.

\section{Ucapan Terimakasih}

Ucapan terima kasih disampaikan kepada semua pihak terutama Laboratorium Lapang Fakultas Peternakan Universitas Kanjuruhan Malang yang telah banyak membantu sejak persiapan hingga terselenggaranya penelitian ini dengan baik.

\section{Daftar Pustaka}

Anonimouse. 2009. Info-Peternakan. Blogspo.com/2011/07/Pengertian-Pakan-Ransum. Html. Diakses melalui internet pada hari rabu tanggal 11 Maret 2015 pukul 11.13 WIB. Malang.

Agus, A. 2007. Membuat Pakan Ternak Secara Mandiri. Citra Aji Pratama. Yogyakarta.

Aguskrisnoblog.wordpress.com/2011/12/27/https: I/pemanfaatan-bakteri-rhizopusoryzae-dalam-industri-tempe/. Diakses melalui internet pada hari selasa tanggal 10 Maret 2015 pukul 23.07 WIB.Malang.

Ayuni, N. 2005. Tata Laksana Pemeliharaan dan Pengembangan Ternak Sapi Potong Berdasarkan Sumber Daya Lahan di Kabupaten Agam, Sumatera Barat. Skripsi. Fakultas Peternakan Institut Pertanian Bogor.

Bugiwati, S. R. A. 2006. Seleksi Pejantan Unggul Sapi Bali Melalui Pendugaan Sifat Karkas dengan Menggunakan Alat Bantu Ultrasonografi. Laporan Hibah Bersaing XIII, Makasar.

Komar, A. 2004. Teknologi Pengolahan Jerami Sebagai Bahan Makanan Ternak. Bandung : Dian Grahita.

Aguskrisnoblog.wordpress.com/2011/12/27/ https: $\quad$ pemanfaatan-bakteri-rhizopusoryzae-dalam-industri-tempe/. Diakses melalui internet pada hari selasa tanggal 10 Maret 2015 pukul 23.07 WIB.Malang.

Mersyiah, R. 2005. Desain Sistem Budidaya Sapi Potong Berkelanjutan Untuk Mendukung Pelaksanaan Otonomi di Kabupaten Bengkulu Selatan. Diserati, Sekolah Pasca Sarjana, Institut Pertanian Bogor. 


\section{Jurnal Sains Peternakan}

Vol 6 No 2, Desember 2018, 34-41

ISSN 2579-4450

Mulyono, S dan Sarwono, B., 2004. Beternak Domba Profilik. Penebar Swadaya. Jakarta.

Ningrum, W. 2004. Pengaruh Dosis Inokulum dan Lama Inkubasi dari Produk Campuran Ampas Sagu dan Ampas Tahu Fermentasi Dengan Kapang Neurospora Crassa. Skripsi S1. Fakultas Peternakan Universitas Andalas.

Purnama J dan T.P.Note.,2006. Jerami Fermentasi Sebagai Pakan Alternatif Bagi Ternak Sapi Pada Musim Kemarau.www.data base.deptan.go.id. Akses 10 Maret 2015.

Purba, C.A.S, 2009. Pengaruh jenis konsentrat Sumber Energi Terhadap Produk Fermentasi Rumen Yang Diberi Jerami Padi Amoniasi Secara In Vitro. Skripsi. Fakultas Peternakan. Universitas Jendral Soedirman.

Retnowati, D dan Susanti, R. 2009. Pemanfaatan Limbah Padat Ampas Singkong dan Lindur Sebagai Bahan Baku Pembuatan Etanol. (Tugas Akhir). Teknik Kimia Universitas Diponegoro. Semarang.

Septiani, Y., 2004 , study kadar karbohidrat,lemak,dan protein pada kecap dari tempe,skripsi fakultas MIPA UNS,Surakarta

Setyorini, A. 2007. Pengaruh Suplemen Ampas Tahu, Ampas Tempe, dan Ampas Kecap dalam Ransum terhadap Performan Domba Lokal Jantan. Sripsi S1. Fakultas Pertanian UNS. Surakarta

Sukaryana, Y, U. Atmomarsono, V. D. Yunianto, E. Supriyatna. 2011. Peningkatan Nilai Kecernaan Protein Kasar dan Lemak Kasar Produk Fermentasi Cmpuran Bungkil Inti Sawit dan Dedak Padi Broiler. JITP, 1(13) :167-172.

Soeroso. 2004. Performans Sapi Jawa Berdasarkan Sifat Kuantitatif dan Kualitatif . Universitas Diponegoro. Semarang.

Sodiq, A, Dan Z, Abidin., 2002. Kiat Mengatasi Permasalahan Praktis Penggemukan Domba. Agro Media Pustaka, Jakarta.

Sudarmono, A.S dan Y.B. Sugeng,2003. Penggemukan Domba. Agro Media Pustaka. Jakarta.

Syafrial, Zubir, A. Yusri dan E. Susilowati 2007. Manajemen Pengemukan Sapi Potong. Laporan Hail Pengkajian Balai Pengkajian Teknologi Pertanian Jambi.

Winarti cit Hidayah., 2009. Pengaruh PenggunaanSekam (Rice Hulls) Fermentasi Dalam Ransum Terhadap Performan Domba Lokal Jantan. Skripsi S1 Fakultas Peternakan Universita Sebelas Maret. Surakarta. 